\title{
STATUS OF HEPATITIS B VACCINATION AMONG HEALTH CARE WORKERS IN A RURAL TERTIARY HOSPITAL
}

Umesh Kawalkar ${ }^{1}$, Prashant Dahire ${ }^{2}$, Vandana Kakrani ${ }^{3}$, Priti Kogade ${ }^{4}$, Vinod Vedpathak ${ }^{5}$, Dipali Deo ${ }^{6}$

\section{HOW TO CITE THIS ARTICLE:}

Umesh Kawalkar, Prashant Dahire, Vandana Kakrani, Priti Kogade, Vinod Vedpathak, Dipali Deo. "Status of hepatitis B vaccination among health care workers in a rural tertiary hospital". Journal of Evolution of Medical and Dental Sciences 2013; Vol2, Issue 39, September 30; Page: 7564-7567.

ABSTRACT: Healthcare workers have high risk of occupational exposure to many bloods -borne disease. Among the high risk groups like healthcare workers, a proportion of vaccinated health care workers are very low. It is in this context that this study was conducted to know the vaccination status among healthcare workers. Descriptive cross-sectional study was done SRTRGMC Ambajogai. Only 35.05\% (135) were completely vaccinated \& majority of group $54.12 \%$ ( 210) were not vaccinated. Main reason for not taking doses in student nurses was that they did not know about vaccination $60 \%$.

KEYWORDS: Healthcare workers; Hepatitis B vaccination.

INRODUCTION: Healthcare workers have high risk of occupational exposure to many blood -borne disease including HIV, Hepatitis B, \& hepatitis C. Out of these hepatitis B is not only most infectious but only disease which is preventable by vaccination also ${ }^{1}$. In developing countries like India the sero- prevalence of hepatitis B among Healthcare workers is 2 to 4 times higher than that of general population ${ }^{2}$.

Effective vaccines are available against hepatitis B since 19821. But even among the high risk groups like healthcare workers; a proportion of vaccinated health care workers is very low. It is in this context that this study was conducted to know the vaccination status among healthcare workers

MATERIALS AND METHODS: Descriptive cross-sectional type of study was done at S.R.T.R. Medical College \& Hospital Ambajogai, Dist -Beed Maharashtra, India. Operational definitions used in the study were complete vaccination: taken $0,1 \& 6$ all the three doses; Partial Vaccination: taken one or two doses only and not vaccinated (nil): not taken single dose. Study was conducted in 388 healthcare workers in the month of Dec 2010 after their informed verbal consent. Resident doctors, Interns, Staff nurse, Student nurse \& Lab. workers from blood bank, Pathology lab, Biochemistry lab, ART centre lab etc. were included in the study. Interview based semi structured \& closed ended questionnaire was used for collecting the data. Ethical clearance was taken from institutional ethical committee.

RESULTS: Out of 508 healthcare workers a total 388(76.37\%) healthcare workers were included in the study.

\begin{tabular}{|c|c|c|}
\hline Participants & Total & No. of participants \\
\hline Resident doctors & 140 & $90(64.28 \%)$ \\
\hline Interns & 52 & $40(76.92 \%)$ \\
\hline Staff nurse & 200 & $148(74 \%)$ \\
\hline Student nurse & 60 & $60(100 \%)$ \\
\hline Lab workers & 56 & $48(85.71 \%)$ \\
\hline
\end{tabular}




\section{ORIGINAL ARTICLE}

\section{Total \\ 508 \\ $388(76.37 \%)$}

Table 1: Participants involved in study

Out of 388 health care workers only 135 (35.05\%) were completely vaccinated \& majority of group 210 (54.12\%) were not vaccinated.

\begin{tabular}{|c|c|c|c|c|c|}
\hline Healthcare workers & I dose & II doses & III doses & not taken & Total (100\%) \\
\hline Resident doctors & $4(4.4 \%)$ & $8(8.8 \%)$ & $70(77.7 \%)$ & $8(8.8 \%)$ & 90 \\
\hline Interns & $5(11.9 \%)$ & $3(7.14 \%)$ & $28(66.6 \%)$ & $6(14.28 \%)$ & 42 \\
\hline Staff nurses & $6(4.05 \%)$ & $10(6.75 \%)$ & $34(22.97 \%)$ & $98(66.21 \%)$ & 148 \\
\hline Student nurses & 0 & 0 & 0 & $60(100 \%)$ & 60 \\
\hline Lab. Workers & $4(8.33 \%)$ & $2(4.16 \%)$ & $4(8.33 \%)$ & $38(79.16 \%)$ & 48 \\
\hline Total & $19(4.88 \%)$ & $23(5.92 \%)$ & $136(35.05 \%)$ & $210(54.12 \%)$ & 388 \\
\hline
\end{tabular}

Vaccination status among healthcare workers was not satisfactory none of the student nurse had taken an even single dose of vaccine.

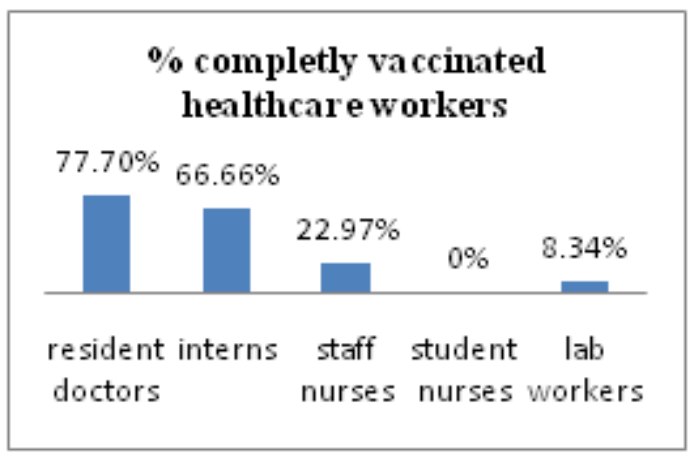

\section{Figure1: Completely vaccinated healthcare workers}

Main reason for not taking doses in student nurses was that they did not know about vaccination 57 (60\%).

\begin{tabular}{|c|c|c|c|c|c|c|}
\hline Reasons & $\begin{array}{c}\text { Resident } \\
\text { doctors }\end{array}$ & $\begin{array}{c}\text { Interns } \\
(\%)\end{array}$ & $\begin{array}{c}\text { Staff } \\
\text { nurses (\%) }\end{array}$ & $\begin{array}{c}\text { Student } \\
\text { nurses (\%) }\end{array}$ & $\begin{array}{c}\text { Lab workers } \\
(\%)\end{array}$ & $\begin{array}{c}\text { Total } \\
(\%)\end{array}$ \\
\hline Not known & 0 & 0 & $10(10.5)$ & $57(60)$ & $28(29.47)$ & 95 \\
\hline Not believe & 0 & 0 & $28(77.7)$ & 0 & $08(22.2)$ & 36 \\
\hline $\begin{array}{c}\text { Lack of } \\
\text { motivation }\end{array}$ & $09(20)$ & $08(17.7)$ & $36(80)$ & 0 & $01(2.2)$ & 45 \\
\hline $\begin{array}{c}\text { Forget next } \\
\text { dose }\end{array}$ & $11(28.2)$ & $06(15.3)$ & $16(41.2)$ & 0 & $06(15.3)$ & 39 \\
\hline $\begin{array}{c}\text { Concern about } \\
\text { side effect }\end{array}$ & $01(2.5)$ & $01(2.5)$ & $24(60)$ & $03(5)$ & $11(27.5)$ & 40 \\
\hline \multicolumn{7}{|c|}{ Table 3: Reasons for not taking vaccination } \\
\hline
\end{tabular}

Table 3: Reasons for not taking vaccination 


\section{ORIGINAL ARTICLE}

DISCUSSION: Main highlight of the study was that only 35\% healthcare workers were vaccinated which was far less than developed countries (75-80\%)2. Other studies from India i.e. Delhi, AIMS \& Armed Forces Hospital, India reported 55.4\%, 52-59\% \& 57.7\% 3,4 respectively were fully vaccinated. Another important aspect of the study was that none of the student nurses had taken even a single dose. Reason behind this is that most of them do not know about vaccine which may be due to all of them come from rural area. Studies reported that maximum occupational risk of HBV was during training and early years of health profession when exposure is maximum and awareness of blood borne pathogen is minimal'2.

Complete vaccination in staff nurses $(22.97 \%)$ and laboratory workers (8.34\%) were also far from satisfactory in our study. This was much higher reported from study Armed Forces Hospitals, India in which nursing 29\% \& paramedical staff 59\% had complete vaccination ${ }^{4}$. Main reason for not taking vaccination in our study was lack of knowledge (35.98\%) and lack of motivation (20.45\%).Attitude \& knowledge regarding non vaccination were important reason from study from Armed Forces Hospital, India 4 .

CONCLUSION: Majority of healthcare workers were not vaccinated. Among various categories of healthcare workers, vaccination status was very low in nurses \& Lab workers .Lack of knowledge about vaccine $\&$ lack of motivation was the important reason for incomplete vaccination.

RECOMMENDATION: It is very important to achieve 100\% vaccination coverage among healthcare workers, not only by providing free immunization facilities by govt. to healthcare workers but it is also necessary to make it mandatory for healthcare workers legally. The study also recommends health education of healthcare workers on occupational risk of hepatitis B \& its prevention.

ACKNOWELDGEMENT: Authors wanted to thanks Dean, SRTRGMC Ambajogai for granting the permission to carry out study

\section{REFERENCES:}

1. WHO | Hepatitis B [Internet]. World Health Organization; [cited 2013 Sep 14]. Available from: http://www.who.int/csr/disease/hepatitis/whocdscsrlyo20022/en/

2. Singhal V, Bora D, Singh S. Hepatitis B in health care workers: Indian scenario. Journal of laboratory physicians. 2009 Jul;1(2):41-8.

3. Asok Kumar K, Baghel P, Shukla C, Jain M. Prevalence of Hepatitis-B Surface Antigen (HBsAg)Among Health Care Workers. Indian journal of community medicine $\square$ : official publication of Indian Association of Preventive \& Social Medicine. 2000;25(2):2000-42000-6.

4. Surg Cdr Chaudhari CN, Col Bhagat M, Ashturkar A, Surg Capt Misra RN. Hepatitis B Immunisation in Health Care Workers. Medical J of Armed Forces India (MJAFI). 2009;65(1). 


\section{ORIGINAL ARTICLE}

\section{AUTHORS:}

1. Umesh Kawalkar

2. Prashant Dahire

3. Vandana Kakrani

4. Priti Kogade

5. Vinod Vedpathak

6. Dipali Deo

\section{PARTICULARS OF CONTRIBUTORS:}

1. Assistant Professor, Department of Preventive and Social Medicine, SRTRGMC, Ambajogai.

2. Assistant Professor, Department of Preventive and Social Medicine, SRTRGMC, Ambajogai.

3. Professor, Department of Preventive and Social Medicine, Dr. D.Y. Patil Medical College, Pune.

4. MPH Student, Department of Preventive and Social Medicine, JNMC, Sawangi.
5. Assistant Professor, Department of Preventive and Social Medicine, SRTRGMC, Ambajogai.

6. Assistant Professor, Department of Preventive and Social Medicine, SRTRGMC, Ambajogai.

\section{NAME ADDRESS EMAIL ID OF THE CORRESPONDING AUTHOR:}

Dr. Umesh Kawalkar,

Dept. of Preventive and Social Medicine, Swami Ramanand Teerth Rural Government Medical College, Ambajogai, Dist Beed, Maharashtra, India.

Email-umeshkawalkar01@gmail.com

Date of Submission: 18/09/2013.

Date of Peer Review: 19/09/2013.

Date of Acceptance: 24/09/2013.

Date of Publishing: 28/09/2013. 